\title{
Surpassing the era of disengaged acceptance: The future of public discourse on nuclear energy
}

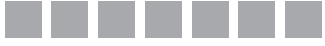 \\ Gabor Sarlos \\ RMIT UNIVERSITY, VIETNAM \\ Mariann Fekete \\ UNIVERSITY OF SZEGED, HUNGARY
}

DOI: 10.19195/1899-5101.11.1(20).5

\begin{abstract}
Both the United Kingdom and Hungary run ambitious nuclear power plans to keep nuclear power as an important element of their energy mixes. The objective of the analysis is to identify if there is the intent and the possibility for a different form of public engagement in shaping the nuclear future. The study builds on the comparative analysis of the cases of Hungary and the United Kingdom. The 'communication packages' theory serves as reference of comparison. The study finds that changing social value sets and communication technology developments create challenges to governments in securing support for the nuclear agenda. This challenge creates an opportunity for members of the public with 'reluctant acceptance' of the nuclear agenda. Building on global uncertainty, challenges to the prevailing political and economic status quo, together with the growing influence of social media might assist the public to become vocal in their opinions about nuclear energy.
\end{abstract}

KEYWORDS: nuclear discourse, disengagement, social values, communication package.

\section{INTRODUCTION}

The current study aims to provide an insight and comparison into the public perception of nuclear energy of the UK and of Hungary. It studies the relevance of the concept of 'public sphere' and of 'communication packages' in the context of current, European discourse. A critical analysis of relevant theories and of contemporary literature sets the context of the study. Then, a comparative analysis assesses how the UK and the Hungarian public resonate to key values relevant to the perception of nuclear energy. Furthermore, the wider context of social and technological changes is also considered. The conclusions indicate a possible direction for the future of nuclear discourse.

The United Kingdom and Hungary envisage ambitious nuclear power development in their long-term energy strategies. In both countries the main argument for 
maintaining and possibly increasing the share of atomic power in the energy mix is that nuclear energy provides a reliable, safe, and affordable source for electricity generation. Proponents of nuclear energy underline the benefits of this source, that easily outweigh possible risks claimed by opponents. The two development plans represent comparable cases due to strong and ambitious government commitment, their dependence on foreign technology and financing, a high level of politicization of the nuclear agenda, and being set against the context of nuclear energy losing its role against renewable energy sources (Schneider et al., 2017). Primarily, the perception of benefits and risks determine support or opposition to nuclear power (Eiser et al., 1990).

\section{Nuclear energy in the United Kingdom}

The UK is home to an ambitious nuclear development program that focuses on the replacement of aging nuclear power capacity through the installation of new nuclear power stations. The Long Term Nuclear Energy Strategy (Department of Energy and Climate Change, DECC, 2013) considers nuclear energy, next to renewables and Carbon Capture and Storage (CCS) (DECC, 2013, p. 5) the fundamental elements of the energy mix. The government sees the role of nuclear as 'delivering a much larger amount of generation than that available now, with the potential to deliver up to $75 \mathrm{GW}$ of the UK's energy needs' (DECC, 2013, p. 6). Fourteen of the current fifteen reactors would see their original life cycle expire soon, and will probably need their life cycle extended. Replacement of ageing plants will need significant development of nuclear power generation capacities, increasing the share of nuclear power in energy generation requires installation of further new capacities. Both the current and planned number of nuclear power plants (Schneider et al., 2016) and the $21 \%$ total share of nuclear energy (World Nuclear Industry Status Report, 2016) makes the country, by planned total nuclear output, one of the significant producers and users of nuclear energy in Europe.

The nuclear development program builds heavily on the involvement of foreign financing and technology. With no restriction on foreign equity and technology, the ambitious nuclear development program and the installation of new nuclear power stations relies heavily on the involvement of French, Chinese, Korean and Japanese technology and financing.

In contrast to a number of other European countries, the Fukushima accident in 2011 did not have any significant impact on government nuclear policies and the commitment to nuclear energy build-up. Tightening of security standards, a more thorough risk analysis process and the consequent rise in planning, financing, building, and operational costs match global trends.

\section{Nuclear energy in Hungary}

With four reactors, Hungary's nuclear power capacity is focused in the city of Paks, providing approximately 50 per cent of the electric power needs of the coun- 
try. The current plant would see its closure in the mid-2030s. Earlier, the government proposed plans to have two new on-site reactors built, and in March 2009 the plan received approval by the Hungarian Parliament. The National Energy Strategy 2030 (Nemzeti Fejlesztési Minisztérium, 2012), approved by the government in 2012, puts 'Atom - Coal - Green' in its focus. With this expansion the share of nuclear energy will rise to 53 percent (World Nuclear Industry Status Report, 2016) and Hungary will stay among the important users of nuclear energy in Europe. The government perceives this move as a lifetime extension, while opponents to the program see it as a de facto expansion of nuclear capacities.

The extension/expansion of the Paks nuclear power plant is based on Russian involvement. Technology and a significant part of the actual construction are supplied by Rosatom, while, financing up to the extent of 80 per cent is covered through a credit from the Russian state-owned VEB bank. The government awarded building and financing rights directly to Russian partners.

\section{METHODOLOGY}

The situation of the nuclear programs of the United Kingdom and Hungary is identified through comparative analysis. The choice of comparative analysis reflects the significant similarities of the nuclear cases in both countries, in terms of their ambition, political support, scope, and reliance on foreign involvement. The analysis tests the validity of the Gamson - Modigliani model within the current political and social conditions in the two countries.

The model (Gamson, Modigliani, 1989) creates a comprehensive framework of requirements for credible communication packages in the field of nuclear energy. The model looks at the main periods of nuclear communication: the post war period where nuclear energy was envisaged as the symbol of modern and robust development, the rise of the anti-nuclear movement in North America and Western Europe in the 1960s and 70s, and the accidents of Three Mile Island in 1979 and in Chernobyl in 1986, resulting in fractures in the myth of the supremacy of nuclear energy.

To interpret the relevance of the model today, validity checking is combined with the comparative analysis of the cases of the UK and Hungary. The three criteria of the Gamson-Modigliani model defining the critical factors of credible "communication packages" allow for a step-by-step analysis of nuclear communication in the two countries.

\section{LITERATURE REVIEW}

In the analysis of media discourse and public opinion on nuclear power, Gamson and Modigliani (1989) label the complex set of communication elements, including claims, catchphrases, metaphors, symbolic elements, and visual pictures as 'pack- 
ages'. Various issues have their set of competing communication packages, and giving preference to one over the other is the decisive factor in actually winning public support. Having competing packages is a necessary prerequisite of open discourse, but, in the case of nuclear power, the authors claim that with public officials being the 'sponsors' of nuclear policy and communication, open discourse is made difficult. Furthermore, Gamson and Modigliani argue that every policy issue and discussion has its own culture, therefore relevant discourse is specific and characteristic to nuclear energy itself.

Kinsella identifies four important characteristics of the nuclear sphere. In his work about the history of nuclear discourse in the USA (Kinsella, 2005) mystery, entelechy, potency, and secrecy are seen as the main descriptors of nuclear communication. The positioning of nuclear energy as something that is 'off limits' to the everyday person creates a unique position to this type of energy source. Use of the four main themes set restrictions on the discourse, and contribute to the creation of 'docile citizens', implying that the issue of nuclear energy is too complex, important, and specialist knowledge intensive, than to leave it with the public.

Catellani (2012) reiterates the findings of Kinsella and confirms its relevance in the European context. Catellani argues that in the field of nuclear discourse the actual disempowerment of the European citizen has taken place. Members of the public are not given any opportunity to take part in the nuclear discourse and the actual decision-making. Catellani supports Kinsella's notion of the dominance of the modernistic narrative, positioning nuclear energy as a 'guarantee' to modernization, growth, and development, in both economic and social terms. In reference to Umberto Eco (1976), Catellani urges the adoption of non-ideological persuasive statements, to build open and transparent discourse in the field.

The discourse can be set in a different context in the light of energy transition (Wagner et al., 2016). In this interpretation the reconceptualizing of the production and use of energy should not only refer to its technological-economic context, but also to its social conceptualization. Wagner et al. claim that in the period of energy transition public thinking is going through a significant transformation, consequently it should be involved in the relevant discourse. They confirm that a strong distinction exists between micro and macro theories of deliberative democracy (Hendriks, 2006; Lehtonen, 2010), arguing that actual discourse appears on the micro level with higher probability than on the macro level. Small group sizes and transparent conditions can maximize efficiency of the discourse, while on the macro-level, the complexity of the issue, the number of actors involved and the complexity of interrelated discourses create a considerable challenge to public discourse. The strong distinction is further validated by underlining a significant difference in the context of the state (Hendriks, 2006). Micro deliberation is described as a range of collaborative practices, with and within the state framework, while theorists of macro deliberation grant validity to the discourse as long as it takes 
place outside and against the state. In conclusion, Wagner et al. raise significant doubts regarding the possibility of an open discourse on nuclear related matters.

\section{DISCUSSION}

\section{Gamson-Modigliani model, criteria 1:}

Communication packages on nuclear energy culturally need to fit well

In the United Kingdom the strong political drive towards nuclear energy is matched by limited public support. In three of the seventeen pieces of research overviewed by a British Parliament committee, the majority showed a clear but conditional support to nuclear energy, eight reflected a division of public attitudes, while in a further six the majority refused the extended use of nuclear energy (Sarlos, 2015a). Analysis of the research results demonstrates that, especially when set in the context of climate change, the population indicates 'it can live with nuclear energy', but expresses 'reluctant acceptance' (Bickerstaff et al., 2008). This is elaborated further by arguing that due to the complexity of the issue, changing public opinion on nuclear issues is not simply a task of disseminating public information (Corner et al., 2011). Reframing the issue in the context of climate change or energy security has limited scope only. That part of the public that, due to its individual value set, has an issue with nuclear energy, will not become supportive of atomic power. Due to individual cognitive dissonance and controversies in the context of climate change, new systems of communication are envisaged (Bickerstaff et al., 2008).

In the UK the Fukushima accident left the level of public support for nuclear energy intact. Following a dive in June 2011, support for nuclear energy regained and in fact, actually surpassed its previous level (Wallard et al., 2012, p. 8). Experts claim that in the UK there has hardly been any 'Fukushima effect' at all (Knight, 2012). In researching the value components of the UK nuclear discourse, it is claimed that the issue of trust is the critical value defining public discourse (Sarlos, 2015a). A range of authors (Renn and Levine, 1991; Johnson, 1999; Poortinga and Pidgeon, 2003b; Poortinga et al., 2006) confirm that trust in the UK government and the regulatory authorities is essential in having, even if of a reluctant nature, support for nuclear energy.

The issue of trust resonates further in recent developments as well. Most specifically the issue of the Hinkley Point $\mathrm{C}$ project, the leading element of the UK 'nuclear renaissance' seems to have a strong imprint on how the public perceives nuclear energy. Uncertainties regarding the involvement of the French company EDF and Areva as well as Chinese CGNPC in the financial and technological realization of the plan have raised significant public concerns. Public deliberation regarding the viability of the project and the investigation into whether the partners can be trusted in political, technological, and financial terms casts a far reaching shadow on the project. 
In Hungary the focus of the 'communication package' of the government-dominated communication is about energy security. The benefits and value of security in general, and specifically of energy security resonate well with the wider public. Energy security is interpreted as access to a steady flow of energy at affordable prices to the public (IEA, 2017). In the political discourse, energy security is often linked to the concept of (energy) independence or energy self-reliance. Security in these cases is positioned as a matter of national priority (Genys, 2013). The government communication packages on nuclear energy refer to the development of Hungarian nuclear capabilities through the extension of the Paks nuclear power plant, as a key prerequisite to meeting the electricity needs of the public and of industrial modernization.

Opinion polls in Hungary provide a complex insight into the public stand on the issue of nuclear energy. Due to differences in methodology, commissioning organization, wording, order of questions and interpretation of results, opinion polls often differ in the conclusions (Sarlos, 2015b). This confirms research about challenges related to the complexity of polling on nuclear energy related issues and the extreme importance of specific wordings (Mitchell, 1980; Nealey et al., 1983). Analysis of the government-dominated communication and the low level of public involvement in the issue indicate a 'disengaged acceptance' of the nuclear development program.

Comparing value systems of the United Kingdom and Hungary contribute to the understanding of the context in the research of the cultural fit of communication packages.

A comparison of the value systems of the two countries is based on the European Social Survey (ESS). The initiative, set up by the European Commission in 2002, allows for a comparative research in geographical and longitudinal terms. The survey provides comparative data about the social and demographic situation, the political and public preferences, and the attitudes of the population of the member countries. ${ }^{1}$

The authors of this study explored further the issues of security, safety, nature, environment, and the role of government through further data analysis. Respondents had to express to what extent they felt themselves similar to a person, making the following claims: Important to live in secure and safety surroundings", "Important that the government is strong and ensures safety", and "Important to care for nature and environment". Possible answers were the following: "Very much like me", "Like me", "Somewhat like me", "A little like me", "Not like me", "Not like me at

1 The bi-yearly survey reveals information about changes in value sets in the respective countries. The research is representative by age, residence, and qualification, the size of the individual sample range between 1500 and 2000 in the various countries. Data collection is done through personal interviews at the domicile of the respondents, who are chosen based on random sampling. Respondents could express their views through providing answers to the closed questions, responses were ranked along a Likert scale. 
all". To ease interpretation of the data, authors transformed the scale further to three grades: the first two, the middle two and the last two options were consequently merged.

Figure 1. Important to live in secure and safe surroundings - HU, UK (in percent)

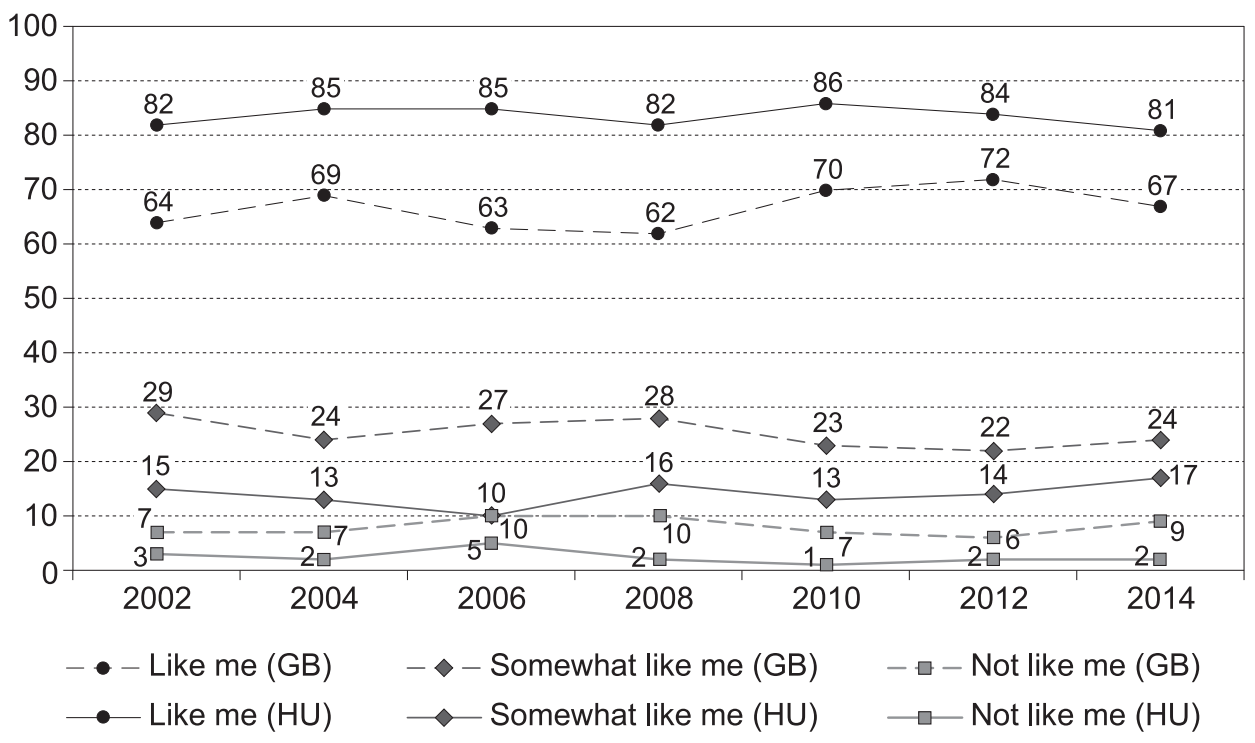

Source: Authors.

Living in a safe and secure environment has been a long-standing, standard value in Hungary, only a small part of the respondents do not identify with this value. For citizens of the United Kingdom, living in a safe and secure environment is of less importance. There are fewer people with full agreement to the statement than in Hungary, while those who somewhat agree or do not agree with the statement exceed those of their Hungarian counterparts (Figure 1). Furthermore, longitudinally the UK responses reflect certain fluctuation. In the case of Hungary, earlier pieces of research (Róbert \& Nagy, 1998) confirm public expectance of a high level of state involvement in public issues. This is primarily due to the legacy of the 'Communist' period with its paternalist thinking, and the loss of security, increase in unemployment and general social decline following the changes in 1990.

This attitude is confirmed when the issue of government involvement is addressed (Figure 2). Along the full period between 2002 and 2014, members of the Hungarian population clearly express a strong desire for security provided by the government. About three quarters of the population share these views, while a further quarter or fifth are hesitant. Over the period, only a marginal part of the respondents (3-5\%) indicate that they do not expect a strong government presence and providing of security. 
Figure 2. Important that the government is strong and ensures safety - HU, UK (in percent)

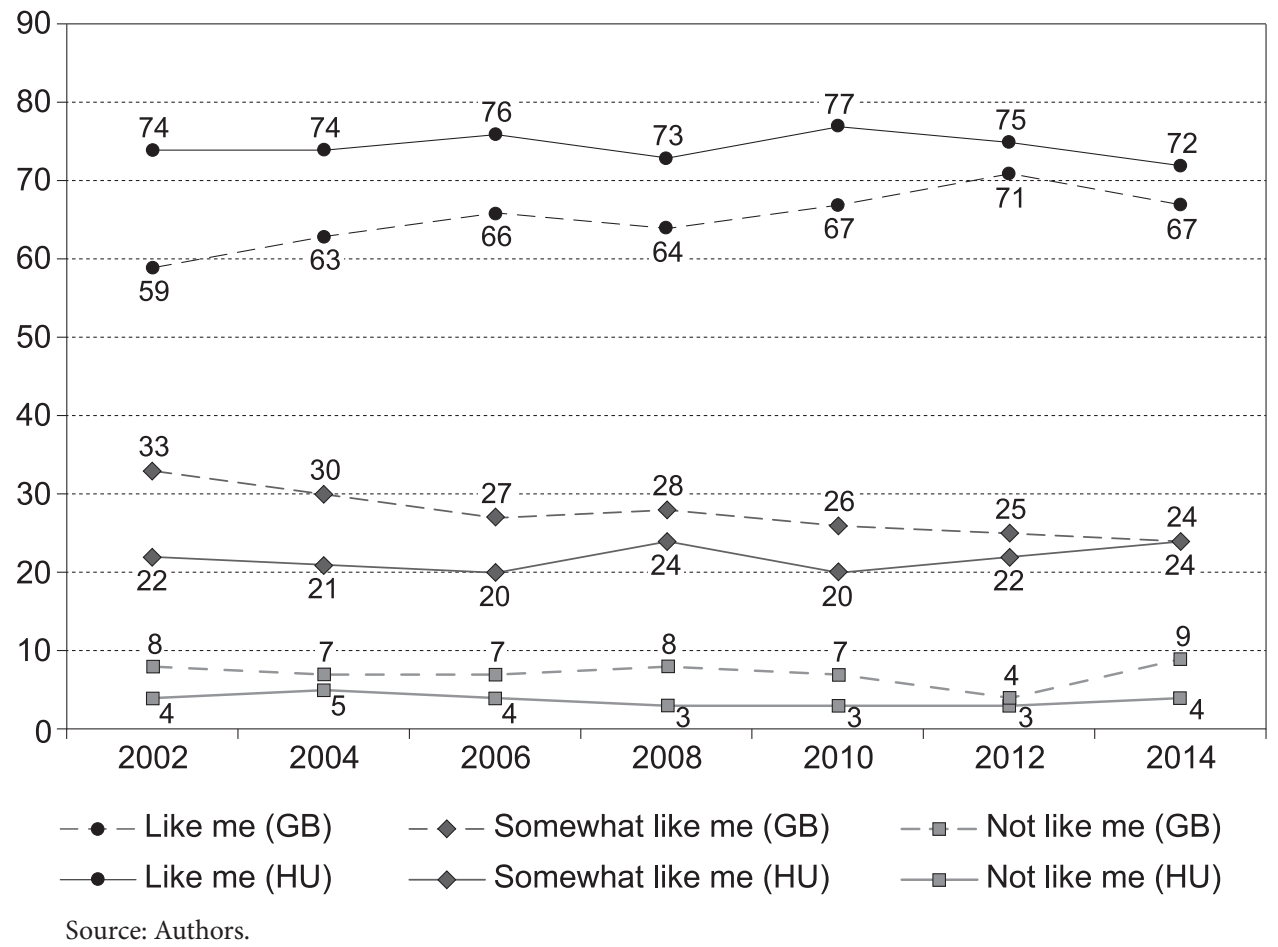

In contrast to this desire for stability, the answers from the United Kingdom reflect changes in attitudes. Until 2012 there was a constant rise in the proportion of those who were looking forward to a strong government. Development of this trend was parallel to the gradual decrease in those being hesitant about this issue. Until 2012, those denying the need for a strong state represent a constant $8 \%$, then their share dropped by half, just to re-emerge and more than double within 2 years. In spite of the growing desire for the involvement of the state, it still 'lags behind' the results in Hungary. Again, value levels in the United Kingdom show signs of fluctuation in the last few years.

The third question discussed the attitude to the environment. For a long time, care for nature and the environment has been a highly regarded value in Hungary, at least on the level of attitudes. In the same period, the United Kingdom has seen a gradual increase in the importance of caring for the environment. In both countries, only a marginal part of the population states that they would not care about nature and the environment (Figure 3).

In summary, the Hungarian public considers security and safety significantly more important than the UK public, finds a strong government providing safety more important than those living in the UK, and consider themselves more caring for nature and the environment than UK citizens do. Furthermore, 
Figure 3. Important to care for nature and the environment - HU, UK (in percent)

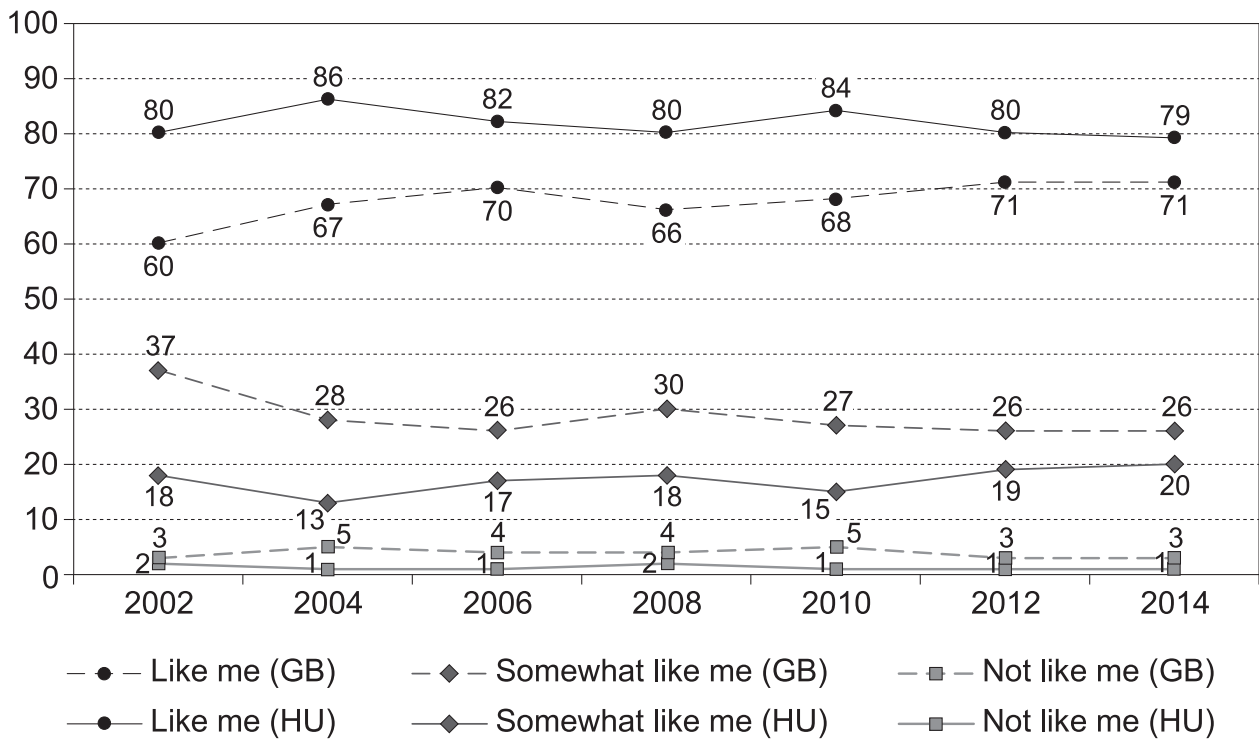

Source: Authors.

value systems in the UK appear to fluctuate more significantly than they do in Hungary.

Propelled by a range of political, economic, social, and cultural factors, public concerns are raised globally in a variety of fields. The fundamental fabric of trust in government, institutions, media, businesses, and NGOs is shaking, the 'population rejects established authority' (Edelman, 2017). Nuclear energy is often pictured as a symbol of political elitism, with governments being the main drivers behind the development programs. It is to be seen if the issue of nuclear energy, as a 'part of the traditional representation of the elite' remains untouched in the rise against elitism. A fracture might emerge between shifting of fundamental global values and the rigidity of value sets related to nuclear energy. In the interpretation where mystery, entelechy, potency, and secrecy are the main characteristics of nuclear energy (Kinsella 2005), it is to be seen if the 'white elephant' of nuclear energy remains intact.

The core values of trust and security identified in the United Kingdom and in Hungary might see changes in the future, as already by indications of change since 2012. Arguably, the world is entering an age of uncertainty where significant aspects of life are strongly affected by fundamental actual and cognitive changes. In an age of growing uncertainty, where people lose their grip with the constant factors of their life, there is a growing search for elements they can trust and elements that provide security in their life. Centralized authoritarian structures and decentralized micro-society focused solutions can both become attractive models, it is yet to be seen where nuclear energy fits in this situation. 


\section{Gamson-Modigliani model, Criteria 2:}

'Communication packages' need to have sponsors with interest in the given package

Development and implementation of nuclear energy policies and programs have always relied on government initiatives and involvement. The period of nuclear armament, followed by the decades of the 'peaceful atom', reactions to the emergence of the anti-nuclear movement, the resonance of the Three Mile Island, Chernobyl, and Fukushima accidents all carry proof that nuclear power development presupposes state initiative, governance and control. In the post-Fukushima period, governments have taken an even more critical role in redesigning and tightening security measures for nuclear power plants. Tightened safety and security measures for planning and building nuclear power plants resulted in extension of timeframes and delays in processes. Investors are looking for additional guarantees to secure their returns, ultimately leading to the demand of state guarantees against risks in the form of additional insurance, retail electricity prices set on a long term and coverage by state guarantee. State involvement is the only reason why and how nuclear power development plans can become viable (Schneider et al., 2017). This further increases the role of governments and secures their on-going vested interest in the success of these developments.

In the field of energy policy, the United Kingdom balances traditionally between market forces and the drive for central control (Keay, 2016). Government plans are often tied up in contradictory objectives and in the end, with the ambition of letting both market forces and central control rule, result in usually highly priced commitments (Keay, 2016). It has been demonstrated to members of the European Parliament, that Hinkley Point, with the UK government agreeing to future buying of electric power at $£ 92.5 / \mathrm{MWh}$, together with indexation to inflation and to be reviewed at a period of 15 and 25 years, has agreed to unnecessarily high concessions, and took on itself critical levels of risk that are difficult to assess (Thomas, 2015).

The government has a strong interest in the success of the communication package, however, the most important argument for nuclear energy, however, the case of climate change seems to stand less and less firm. The environmentally strongly committed part of the public does not approve nuclear energy as an alternative, and their concern about climate change, together with energy security, has a limited impact on increasing agreement to the use of nuclear energy (Corner et al., 2011). The business case is burdened by the financial issues of international, primarily the French investors, and the political case is questioned due to the exposure to foreign, primarily Chinese influence. All this is challenged further by the fast technological rise and steep cost decrease of renewable energy sources, which in the end means a growing competition for nuclear energy. All of these have an impact to a possible decrease in government dedication to the sponsorship of this communication package.

Especially since signing the agreement on relying on Russian technology and financing, the Hungarian government has been the key supporter of the nuclear 
communication package, and it has been the driver of the discourse. Government communication builds on the fundamental messages of self-reliance and energy independence, even if both nuclear technology and fuel are import sources. To some extent it can also use the involvement of state owned Russian companies and banks to symbolize the "anti-Brussels" nationalism of the Hungarian government. In its current state, with disengaged acceptance and ignorance of the issue by the wider public, and the de facto low profile in the media and keeping it within the elitist - political array (Wagner et al., 2016), the nuclear business seems to be continuing as usual.

In the messaging, the government does not overemphasize the role Russia plays in the development, even if it has its interest in keeping Russia capable of meeting its commitment, and deliver the new reactors by the deadline and within the agreed financial framework. The former is questioned by significant delays and financial turmoil of internationally comparable projects, such as Olkiluoto in Finland and Flamanville in France, while the latter is challenged by uncertainties about the solvency of Russian financial institutions.

The post-Fukushima changes of the nuclear scene have not left the United Kingdom and Hungary unaffected. While public support and opposition does not seem to reflect on the 2011 accident, the general rise in uncertainties leave an imprint on government commitments. Increased risks, additional budgetary requirements, extended planning and construction times and increased state involvement have all caused governments to be more cautious. While the commitment of the UK and Hungarian government to the nuclear agenda might be unchanged, there are signs of caution by keeping a more modest public stance on nuclear issues. The intent is clearly to keep the issue in the realms of technical - technological - energy policy issues and not to expose it in the public discourse.

Gamson-Modigliani model, Criteria 3:

Communication packages need to fit the relevant media patterns

Two contradictory trends can be noted in reviewing media acceptance of nuclear energy. Independent media tend to deliver a more accurate account on the possible risks of nuclear energy and their account on accidents tends to be more and more accurate. However, having strong commercial interests might as well lead to inaccuracies in favor of publicity, through exaggeration or search of sensationalism. On the other hand, media under significant government influence might have better access to factual information, but still, might modify or limit its output of information about risks and accidents (Perko, 2011). Traditionally, media patterns tell that media more sympathetic to actual pro-nuclear governments are inclined to underline the benefits, while media with a critical approach to nuclear energy and the government rather emphasize the risks.

Traditional media patterns are being challenged by fundamental changes in media ownership, structure, and technology. Social media may open new channels 
of communication and requires different attitudes. In overall terms, the rise of social media could allow for the emergence of a diversity of views, by allowing everyone equal access to information. Internet and social media have achieved a distinguished role in becoming whistle-blowers regarding transparency in nuclear issues. While before the internet era, strong government control prevailed on most media on nuclear-related issues, this grip had to loosen with the rise of widely available internet and social media (Friedman, 2011). With Fukushima being the first major accident in the 'digital age', social media has played a significant role in shaping perception and possibly future policies of nuclear energy.

Nuclear topics seem to be viewed as niche issues, to which people have difficulties to relate to or engage with. This confirms other areas of research, that nuclear concerns are not high on the public agenda. All this might not lead towards the nuclear agenda becoming a topic for social media. Furthermore, in the 'post-truth' era it is becoming growingly apparent that through emission of large amounts of biased information, as well as through the manipulation of social media logarithms, information can be distorted and manipulated. This might question nuclear related information accessed on the internet and in social media, and cast a shadow on sources for reliable information in possible critical periods.

The UK has traditionally enjoyed a high level of freedom of the media. As an overall policy, journalism tends to keep its distance from politics and politicians, and it has a strong commitment to serve society as the representative of the 'Fourth Estate'. Editorial freedom allows for the appearance of a plethora of views, making both pieces of news information and a range of possible interpretations both available (Brüggemann et al., 2014). In the Fukushima case on the spot reporters and back office editorial writers often had contradictory views published. In comparison to some other European countries, the accident in Japan was covered modestly in the United Kingdom and without any indication that it could have a direct relevance to the nuclear agenda (Kepplinger \& Lenke, 2016). The biggest challenge in the UK for nuclear-related communication packages to match the relevant media patterns are the changing media patterns themselves. The traditional approach of the government and the media, based on respect and acceptance, might become under pressure in case the nuclear issues get more focus. In a critical situation, be it for political, financial, or technological reasons, the use of social media might become more viable and in demand.

In Hungary, media has been under constant pressure of three critical and often contradictory factors: government influence, commercial interests and independent journalism. Since 2010, a significant shift has been taking place where a growing part of the traditional and online media landed under strong government influence (Wilkin, 2016). In fact, the Hungarian government and the ruling FIDESZ party have acquired a dominant position to push its communication packages in the media. Hungary is considered a 'classic case of media capture, where the govern- 
ment has used policy and public funding to turn independent media into a mere government establishment' (Dragomir, 2017).

Media attitudes to the nuclear development plan of the country reflect the political sympathy or even affiliation of the given media (Sarlos, 2015a). The balance between risks and benefits of the Paks development plans is a reflection of where the given paper stands in terms of its editorial policy. Critics of the nuclear program are labeled in the media as opponents to the principles of "national self-reliance" and "energy independence" and, in general, positioned as "aliens" (Sarlos, 2015c). The emergence of political alienism (Szabó, 2006) demonstrates a growing public split on a range of issues, and the subject of the nuclear issue might easily land among these issues.

Findings of this analysis coincide with findings from Lithuania and Poland (Genys, 2013; Wagner et al., 2016), due to contextual similarities, including history, traditions, and role of media. Similar splits are confirmed by analyses of nuclear discourses in Belgium, Italy, and France (Catellani, 2012).

Traditional media patterns face two different challenges. First, the massive technological changes result in the decreasing importance of traditional media and contribute to the rise of social media. However, in neither of the two countries does nuclear energy appear to rank high on social media.

Second, the role of government in representing the nuclear case in media differs significantly. In the UK the government represents the nuclear agenda to the media and media would deal with it at its liberty, while in Hungary, the government exercises pressure on the media so that it represents the ambitious development program. Both models seem to fit the relevant media patterns of the country, and reflect a characteristic relationship between the government and media. Analysis of media confirms that the nuclear discourse has been "protected by an institutional web of social and technological practices. Such institutional structures and belief systems engender a restricted view of the scope for public discussion and democratic involvement within nuclear decision-making" (Irwin in Irwin et al., 2000, p. 83). In case the social media becomes interested and involved in the topic of nuclear energy, it might become the new forum for nuclear energy.

In a wider context, the post-Fukushima effect to the perceived infallibility of nuclear power, together with the global value changes taking place might challenge the existing status quo of nuclear energy. In a context of global and local uncertainties, safety, and security, together with the notion of a strong government, become imperative. Non-understanding of the complex issue of nuclear energy, together with the search for security might reinforce the dominance of the 'reluctant acceptance' attitude in case of the understanding of the issue. Non-interest in the issue rather leads to the model of 'disengaged acceptance'. As it is in the interest of governments to keep the nuclear agendas unchallenged, they might encourage further disengagement in the issue by framing it as a safe and secure solution, all guaranteed by a strong state and government. 
However, the rise in the influence of climate skeptics may dilute the power of argumentation that nuclear energy is a carbon-free option, global challenges to elitism and politician power could weaken governments and their nuclear plans, traditional patterns of political representation, elections and decision making are changing, and being based on foreign involvement, political disputes and financing issues can possibly put most projects at risk.

\section{CONCLUSIONS}

By giving a blast to nuclear plans, Fukushima induced a new period for nuclear power development plans and for related government powered communication. It led directly to several countries revising their nuclear development plans, redesign of the safety requirements of nuclear power plants, and a consequent significant increase in the length of planning and construction times and of financial needs. The increase in risks and costs resulted in a major international revision of commitments to nuclear development programs, with some countries abandoning their nuclear energy programs, while others reconfirmed theirs. The United Kingdom and Hungary both reiterated their dedication to continue with their plans.

Nuclear-related communication models will not remain intact. In line with the Gamson-Modigliani model, governments, if they want to continue maintaining credibility of nuclear communication, will need to redesign their communication packages. They need to reflect on the imminent changes in the respective value systems. They need to redesign their tools to engage with the public that currently increasingly manifests an attitude of 'reluctant acceptance' and 'disengaged acceptance'.

Global value changes and challenges to the current status quo, including the dramatic drop in public trust, the elementary changes in the global media landscape, the imminent challenges to communication in the post-truth era and the strong shift in influence from traditional to social media will fundamentally reshape media patterns for nuclear communication. From the public perspective, significant changes in values, the context and content of nuclear communication, together with the media patterns open up new opportunities. This call for new platforms for public discourse on nuclear energy. Social media could become the new frontier for any public discourse on nuclear energy, and it can serve as a significant driver for future social changes, with a strong possible effect on the use of nuclear energy.

\section{REFERENCES}

Bickerstaff, K., Lorenzoni I., Pidgeon, N.F., Poortinga, W., \& Simmons, P. (2008). Reframing nuclear power in the UK energy debate: nuclear power, climate change mitigation and radioactive waste. Public Understanding of Science, 17(2), pp. 145-169.

Brüggemann, M., Engesser, S., Büchel, F., Humprecht, E., \& Castro, L. (2014). Hallin and Mancini revisited: Four empirical types of Western media systems. Journal of Communication, 63, pp. 1037-1065. DOI:10.1111/jcom.12127. 
Catellani, A. (2012). Pro-nuclear European discourses: Socio-semiotic observations. Public Relations Inquiry, 1(3), pp. 285-311.

Corner, A., Venables, D., Spence, A., Poortinga, W., Demski, C., \& Pidgeon, N. (2011). Nuclear power, climate change and energy security: Exploring British public attitudes. Energy Policy, 39, pp. 4823-4833.

Department of Energy and Climate Change (DECC) (2013). The Long Term Nuclear Energy Policy. https://www.gov.uk/government/uploads/system/uploads/attachment_data/file/ 168047/bis13-630-long-term-nuclear-energy-strategy.pdf), retrieved 30 November 2016.

Dragomir, M. (2017). The State of Hungarian Media: Endgame, http://blogs. lse.ac.uk/mediapolicyproject/2017/08/29/the-state-of-hungarian-media-endgame/, accessed 17 December 2017.

Eco, U. (1976). A Theory of Semiotics. Bloomington: Indiana University Press.

Edelman (2017). Edelman Trust Barometer 2017, http://www.edelman.com/global-results/, accessed 26 January 2017.

Eiser, J.R., Hannover, B., Mann, L., Morin, M., van der Pligt, J., \& Webly, P. (1990). Nuclear Attitudes after Chernobyl: A cross national study. Journal of Environmental Psychology, 10, pp. 101-110.

Friedman, S. M. (2011). Three Mile Island, Chernobyl, and Fukushima: An analysis of traditional and new media coverage of nuclear accidents and radiation. Bulletin of the Atomic Scientists, 67(5), pp. 55-65. DOI: 10.1177/0096340211421587.

Gamson, W. A., \& Modigliani, A. (1989). Media discourse and public opinion on nuclear power: A constructionist approach. American Journal of Sociology, 96(1), pp. 1-37.

Genys, D. (2013). The role of scientists in Lithuanian energy security discourse formation. Baltic Journal of Law and Politics, 6(1), pp. 166-183.

Hendriks, C. M. (2006) Integrated deliberation: reconciling civil society's dual role in deliberative democracy. Political Studies, 54(3), pp. 486-508.

International Energy Agency (IEA) website (2017) https://www.iea.org/topics/energysecurity/ subtopics/whatisenergysecurity/, retrieved 6 January 2017.

Irwin, A., Allan, S., \& Welsh, I. (2000). Nuclear risks: Three problematics. In: B. Adam, U. Beck \& J. Van Loon (eds.), The Risk Society and Beyond: Critical Issues for Social Theory. London: SAGE, pp. 78-104.

Johnson, B. B. (1999). Exploring dimensionality in the origins of hazard related trust. Journal of Risk Research, 2(4), pp. 325-354.

Keay, M. (2016). UK energy policy — Stuck in ideological limbo?. Energy Policy, 94, pp. 247-252.

Kepplinger, H. M., \& Lemke, R. (2016). Instrumentalizing Fukushima: Comparing media coverage of Fukushima in Germany, France, the United Kingdom, and Switzerland. Political Communication, 33(3), pp. 351-373. DOI: 10.1080/10584609.2015.1022240.

Kinsella, W. J. (2005). One hundred years of nuclear discourse: Four master themes and their implications for environmental communication. In: Senecah, S. L. (ed.), The Environmental Communication Yearbook, Volume 2. Mahwah: Lawrence Erlbaum Associates, pp. 49-72.

Knight, R. (2012). Nuclear Energy Update Poll. London: Ipsos-MORI.

Lehtonen, M. (2010). Deliberative decision-making on radioactive waste management in Finland, France, and the UK: influence of mixed forms of deliberation in the macro discursive context. Journal of Integrative Environmental Sciences, 7(3), pp. 175-196. DOI: 10.1080/1943815X. 2010.506487.

Mitchell, R. C. (1980). Polling on nuclear power: A Critique of the Polls after Three Mile Island. Polling on the Issues. Washington, D.C.: Seven Locks, pp. 66-98.

Nealey, S. M., Melber, B. D., \& Ranking, W. L. (1983). Public Opinion and Nuclear Energy. Lexington, Mass.: Heath.

Nemzeti Fejlesztési Minisztérium (Ministry of National Development) (2012). Nemzeti Energiastratégia 2030 (National Energy Strategy 2030), http://2010-2014.kormany.hu/download/4/ 
f8/70000/Nemzeti\%20Energiastrat\%C3\%A9gia\%202030\%20teljes\%20v\%C3\%A1ltozat.pdf, retrieved 2 December 2016.

Perko, T. (2011). Importance of risk communication during and after a nuclear accident. Integrated Environmental Assessment and Management, 7, pp. 388-392.

Poortinga, W., \& Pidgeon N. (2003). Exploring the dimensionality of trust in risk regulation. Risk Analysis, 23(5), pp. 961-972.

Poortinga, W., Pidgeon, N., \& Lorenzoni, I. (2006). Public Perceptions of Nuclear Power, Climate Change and Energy Options in Britain: Summary Findings of a Survey Conducted during October and November 2005. Understanding Risk working paper 06-02. Centre for Environmental Risk + Tyndall Centre for Climate Change Research.

Renn, O., \& Levine, D. (1991). Credibility and trust in risk communication. In: R.E. Kasperson and P. J. M. Stallen (eds.), Communicating Risks to the Public. The Hague: Kluwer.

Róbert, P., \& Nagy, I. (1998). Újraelosztó állam vagy öngondoskodó polgár? (Redistributing state or self-sufficient citizens?) In: TÁRKI Társadalompolitikai Tanulmányok 8. Budapest, 1998. http:// www.tarki.hu/adatbank-h/kutjel/pdf/a392.pdf, retrieved 23 January 2017.

Sarlos, G. (2015a). Risk and Benefit Perceptions in the Discourse on Nuclear Energy. Saarbrücken: LAP Lamberts.

Sarlos, G. (2015b). Risk perception and political alienism: Political discourse on the future of nuclear energy in Hungary, Central European Journal of Communication, Vol. 8(14), pp. 93-112.

Sarlos, G. (2015c). A közvéleménykutatások szerepe a magyarországi atomenergia diskurzus alakításában (The Role of Public Opinion Polls in Shaping Hungarian Nuclear Discourse). Jel-kép, 2015(1). pp. 21-38.

Schneider, M., Froggatt, A., Hazemann, J., Katsuta, T., \& Ramana, M. V. (2016). The World Nuclear Industry Status Report 2016, Mycle Schneider Consulting http://www.worldnuclearreport.org/ IMG/pdf/20160713MSC-WNISR2016V2-LR.pdf, retrieved 1 December 2016.

Schneider, M., Froggatt, A., Hazemann, J., Katsuta, T., Ramana, M.V., Rodriguez J.C., Rüdinger A. \& Sitenne, A. (2017). The World Nuclear Industry Status Report 2017, Mycle Schneider Consulting. https://www.worldnuclearreport.org/IMG/pdf/20170912wnisr2017-en-lr.pdf, retrieved 17 December 2017.

Szabó, M. (2006). Politikai idegen (Political alien). Budapest: L’Harmattan.

Thomas, S. (2015). A Comparison of the Hinkley Point and Paks Projects (presentation to the European Parliament, 15 March 2015).

Wagner, A., Grobelskia, T., \& Harembski, M. (2016). Is energy policy a public issue? Nuclear power in Poland and implications for energy transitions in Central and East Europe. Energy Research \& Social Science, 13, pp. 158-169.

Wallard, H., Duffy, B., \& Cornick, P. (2012). After Fukushima - Global Opinion on Energy Policy. Retrieved from http://www.ipsos.com/public-affairs/sites/www.ipsos.com.public-affairs/ files/ Energy\%20Article.pdf, retrieved 5 January 2017.

Wilkin, P. (2016). Hungary's Crisis of Democracy: The Road to Serfdom. Lexington Books.

World Nuclear Association / Country Profiles / Nuclear Power in the United Kingdom (2016) / 25 Nov 2015 (p. 2). http://www.world-nuclear.org/information-library/country-profiles.aspx, accessed 2 December 2016. 